\title{
Pharmacokinetics in Mouse and Comparative Effects of Frondosides in Pancreatic Cancer
}

\author{
Jasem Al Shemaili ${ }^{1}$, Khatija A. Parekh ${ }^{1}$, Robert A. Newman ${ }^{2}$, Björn Hellman ${ }^{3}$, \\ Carl Woodward ${ }^{4}$, Abdu Adem ${ }^{5}$, Peter Collin ${ }^{4}$ and Thomas E. Adrian ${ }^{1, *}$ \\ 1 Department of Physiology, Faculty of Medicine, United Arab Emirates University, P.O. Box 17666, Al Ain, \\ UAE; 201617836@uaeu.ac.ae (J.A.S.); kparekh@uaeu.ac.ae (K.A.P.) \\ 2 Phoenix Biotechnology Inc., San Antonio, TX 78217, USA; rnewman@phoenixbiotechnology.com \\ 3 Department of Pharmaceutical Biosciences, Uppsala University, Uppsala 75105, Sweden; \\ Bjorn.Hellman@farmbio.uu.se \\ 4 Coastside Bio Resources, Deer Isle, ME 04627, USA; carlw@coastsidebio.com (C.W.); \\ petercollin@coastsidebio.com (P.C.) \\ 5 Department of Pharmacology, Faculty of Medicine, United Arab Emirates University, P.O. Box 17666, Al Ain, \\ UAE; abdu.adem@uaeu.ac.ae \\ * Correspondence: tadrian@uaeu.ac.ae; Tel.: +971-3-713-7551
}

Academic Editors: Keith B. Glaser and Peer B. Jacobson

Received: 14 April 2016; Accepted: 6 June 2016; Published: 17 June 2016

\begin{abstract}
The frondosides are triterpenoid glycosides from the Atlantic sea cucumber Cucumaria frondosa. Frondoside A inhibits growth, invasion, metastases and angiogenesis and induces apoptosis in diverse cancer types, including pancreatic cancer. We compared the growth inhibitory effects of three frondosides and their aglycone and related this to the pharmocokinetics and route of administration. Frondoside A potently inhibited growth of pancreatic cancer cells with an $\mathrm{EC}_{50}$ of $\sim 1 \mu \mathrm{M}$. Frondoside $\mathrm{B}$ was less potent $\left(\mathrm{EC}_{50} \sim 2.5 \mu \mathrm{M}\right)$. Frondoside $\mathrm{C}$ and the aglycone had no effect. At $100 \mu \mathrm{g} / \mathrm{kg}$, frondoside $\mathrm{A}$ administered to $\mathrm{CD}_{2} \mathrm{~F}_{1}$ mice as an i.v. bolus, the $\mathrm{Cp}_{\max }$ was $129 \mathrm{nM}, \mathrm{Cl}_{\mathrm{tb}}$ was $6.35 \mathrm{~mL} / \mathrm{min} / \mathrm{m}^{2}$, and half-life was $510 \mathrm{~min}$. With i.p. administration the Cpmax was $18.3 \mathrm{nM}$, $\mathrm{Cl}_{\mathrm{tb}}$ was $127 \mathrm{~mL} / \mathrm{min} / \mathrm{m}^{2}$ and half-life was $840 \mathrm{~min}$. Oral dosing was ineffective. Frondoside A (100 $\mu \mathrm{g} / \mathrm{kg} /$ day i.p.) markedly inhibited growth cancer xenografts in nude mice. The same dose delivered by oral gavage had no effect. No evidence of acute toxicity was seen with frondoside A. Frondoside $\mathrm{A}$ is more potent inhibitor of cancer growth than other frondosides. The glycoside component is essential for bioactivity. Frondoside A is only effective when administered systemically. Based on the current and previous studies, frondoside A appears safe and may be valuable in the treatment of cancer.
\end{abstract}

Keywords: frondoside A; pancreatic cancer; cancer; pharmacokinetics

\section{Introduction}

Pancreatic cancer is a disease with a dismal prognosis and little hope for cure because effective therapies are not available [1]. While the disease is not very common it is a leading cause of cancer death because of the poor prognosis and the difficulty of detecting the disease at an early stage [2]. The mean survival time after diagnosis is about five months and even the subgroup (less than $20 \%$ of patients), in whom potentially curative surgery is an option, rarely survive more than two or three years [2]. Until recently, gemcitabine was the mainstay of therapy for pancreatic cancer patients in neoadjuvant, adjuvant and palliative treatment protocols [3]. While this drug improved quality of life, it has proved to have little effect on survival [3]. New developments in treatment strategies include the use of FOLFIRINOX and Nab-paclitaxel, both of which have shown some survival benefits 
over gemcitabine alone and only time will reveal their overall impact on the disease. However, new therapeutic strategies are urgently required for pancreatic cancer patients [3].

The frondosides are triterpenoid glycosides isolated from the Atlantic sea cucumber, Cucumaria frondosa. Frondoside A has potent antiproliferative, anti-invasive and anti-angiogenic effects on a variety of cancers including adenocarcinomas of the pancreas, breast, lung, and prostate as well as in leukemia [4-8]. Frondoside A has been shown to block cancer cell growth and apoptosis both in vitro, as well as in human cancer xenografts in athymic mice [4-7]. Frondoside A has also been shown to have synergistic effect when combined with gemcitabine in vitro as well as in human cancer xenografts in athymic mice [9]. Additionally, frondoside A has been shown to potently enhance innate immunity in laboratory animals [10], and to show immunomodulatory effects in splenocytes by proteomic analysis [11].

One aim of the present study was to compare the growth inhibitory effects of frondoside A to the other frondosides ( $\mathrm{B}$ and $\mathrm{C}$ ), and the aglyocone compound. These were isolated from the same sea cucumber species-Cucumaria frondosa. Additional aims included investigation of the pharmacokinetics of frondoside A following either i.v., i.p., or oral administration.

\section{Results}

\subsection{Effects on Proliferation of AsPC-1 and S2013 Pancreatic Cancer Cells in Vitro}

Both frondoside A and frondoside B markedly inhibited growth of human AsPC-1 and S2-013 cells (Figure 1). Frondoside A showed similar potency to that of previous reports in these cell lines, while frondoside $B$ was less potent. The different frondosides and their aglycone were examined at concentrations of $2,4,6,8$, and $10 \mu \mathrm{M}$. Frondoside $\mathrm{A}$ at $2 \mu \mathrm{M}$ inhibited cell growth by $70 \%-80 \%$ in AsPC- 1 and S2013 cells at $48 \mathrm{~h}$ and by $90 \%-95 \%$ at $4 \mu \mathrm{M}$ in both cell lines (All $p<0.0001$, Figure 2). Frondoside B inhibited cell growth by around $20 \%-25 \%$ at $2 \mu \mathrm{M}$ in the two cell lines and by about $60 \%-70 \%$ at $4 \mu \mathrm{M}$ at $48 \mathrm{~h}$ (All $p<0.0001$ except frondoside B at $2 \mu \mathrm{M}: p<0.05$, Figure 3). Neither frondoside $C$ nor the aglycone had a significant effect on cell viability at concentrations of 2 and $4 \mu \mathrm{M}$ (Figure 2).
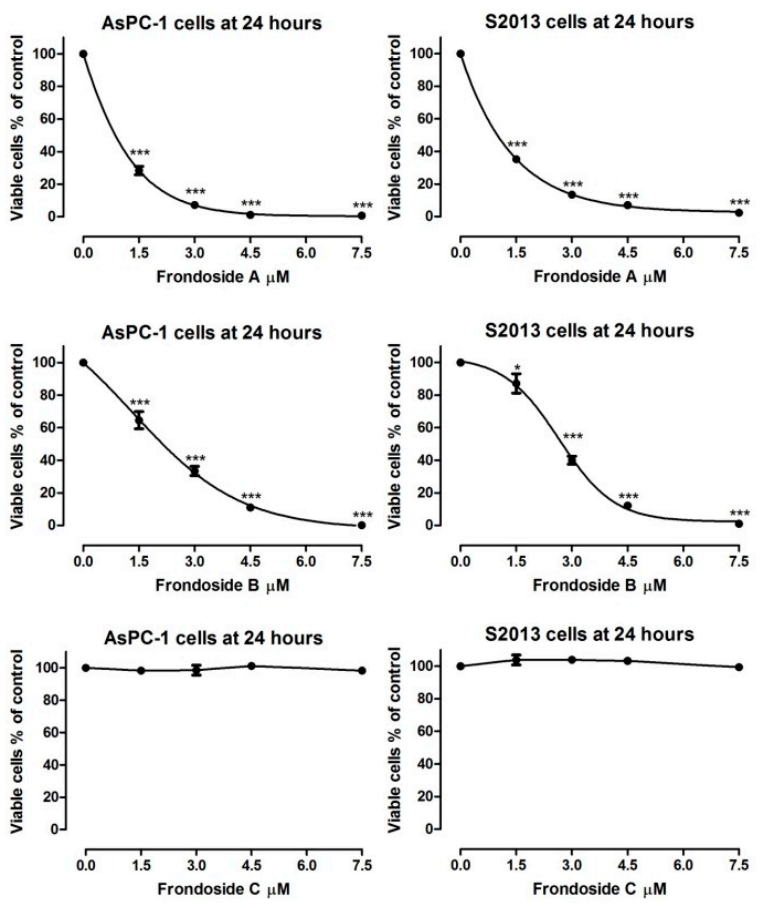

Figure 1. Effects of frondoside A, B and C on viability of AsPC-1 and S2013 human pancreatic cancer cells after $24 \mathrm{~h}$ of incubation. ${ }^{* * *} p<0.001$. 

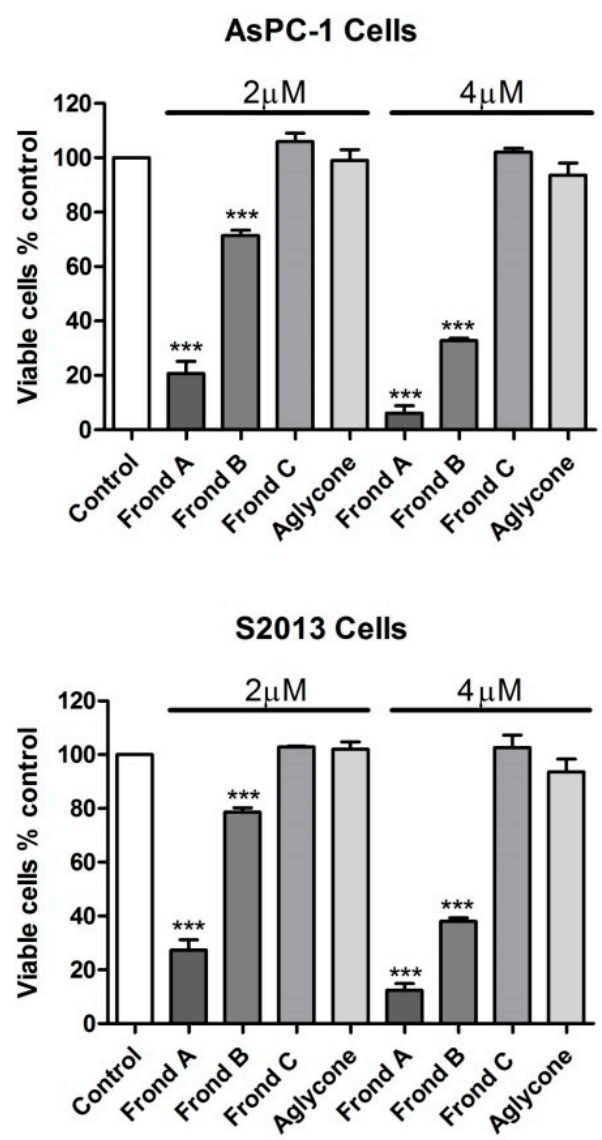

Figure 2. Effects of frondoside A, B and C and their aglycone on viability of AsPC-1 and S2013 human pancreatic cancer cells after $48 \mathrm{~h}$ of incubation. ${ }^{* * *} p<0.001$.

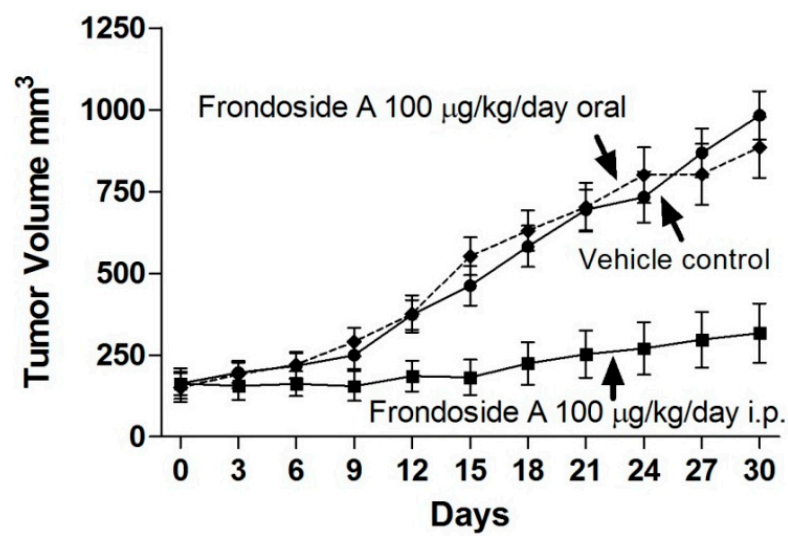

Figure 3. Effects of frondoside A administered either orally or intraperitoneally at a dose of $100 \mu \mathrm{g} / \mathrm{kg} /$ day on growth of AsPC-1 human pancreatic cancer xenografts in athymic mice over a 30-day period.

\subsection{Comparison of Route of Administration of Frondoside A on Growth of AsPC-1 Xenografts in Athymic Mice}

Frondoside A administered via an intraperitoneal route daily at $100 \mu \mathrm{g} / \mathrm{kg} /$ day substantially reduced growth of AsPC-1 xenografts in athymic mice over a 30 day period (Figure 3). In contrast, the same dose administered orally had no effect (Figure 3). When measured as the incremental area under the curve, tumor volume in the intraperitoneal frondoside A-treated group (AUC $1716 \pm 2001$ ) was markedly reduced compared with the control group (AUC 11, $184 \pm 1812, p<0.001$ ), while oral frondoside A had no effect (AUC 11, $844 \pm 2079$ ). 


\subsection{Pharmacokinetics of Frondoside A}

The assay was found to be suitable for measurement of frondoside A in both mouse and human plasma. Accuracy was $88 \%$, within day coefficient of variation $(\mathrm{CV})<8 \%$ for concentrations in the range of $25-250 \mathrm{ng} / \mathrm{mL}$. The limit of detection (LOD) was $5 \mathrm{ng} / \mathrm{mL}$. Results of the ultracentrifugation studies revealed $68 \%-80 \%$ binding of frondoside A to plasma proteins at concentrations between 250 and $100 \mathrm{ng} / \mathrm{mL}$. With regard to stability, there was little change in concentrations of frondoside A in mouse or human plasma incubated at $37^{\circ} \mathrm{C}$ for $1 \mathrm{~h}$, but at $24 \mathrm{~h} 73 \%$ of the initial concentration (200 ng/mL) remained in human plasma while only 50\% remained in mouse plasma. Protein binding was determined by ultracentrifugation. Pilot toxicity studies revealed no acute clinical signs of toxicity following single intravenous (i.v.), intraperitoneal (i.p.), or oral doses up to $300 \mu \mathrm{g} / \mathrm{kg}$. Pharmacokinetic studies were carried out using intravenous (i.v.), intraperitoneal (i.p.), or oral dosing at 100 and $300 \mu \mathrm{g} / \mathrm{kg}$. No adverse acute clinical signs were seen following any of these routes of administration. Plasma levels after i.v. dosing were readily measurable (700-800 $\mathrm{ng} / \mathrm{mL})$. Levels with i.p. dosing were much lower $(\sim 50 \mathrm{ng} / \mathrm{mL})$ and levels after oral administration were near the limit of detection. The definitive study on pharmacokinetics was performed in $\mathrm{CD}_{2} \mathrm{~F}_{1}$ mice with i.v. administration of frondoside A at $100 \mu \mathrm{g} / \mathrm{kg}$.

The pharmacokinetic parameters measured during the i.v. and i.p. experiments are shown in Table 1 and the concentration versus time plots are shown in Figure 4 . The mean $C_{\max }$ following i.v. administration of frondoside A was $129 \mathrm{nM}(172 \mathrm{ng} / \mathrm{mL})$. The $C_{\max }$ following i.p. administration of frondoside A was $18.3 \mathrm{mM}(24 \mathrm{ng} / \mathrm{mL})$ at $45 \mathrm{~min}$, which was approximately 7-fold lower than with i.v administration at the same dose (Figure 4).

The calculated bioavailability after i.p. administration was approximately $20 \%$. Following i.v. dosing, plasma levels of frondoside A remained above $7.5 \mathrm{nM}(10 \mathrm{ng} / \mathrm{mL})$ for $17 \mathrm{~h}$, while for i.p. dosing the plasma concentration remained above this level for only $4 \mathrm{~h}$. Pilot studies with oral doses of 100 and $500 \mu \mathrm{g} / \mathrm{kg}$ demonstrated very low and variable concentrations of frondoside A in plasma that were near to or below the detection limit $(5 \mathrm{ng} / \mathrm{mL})$ of the assay. Pharmacokinetic parameters measured during the i.v. and i.p. experiments are shown in Table 1. Notably, the half-life of frondoside A administered intravenously was $8.5 \mathrm{~h}$.
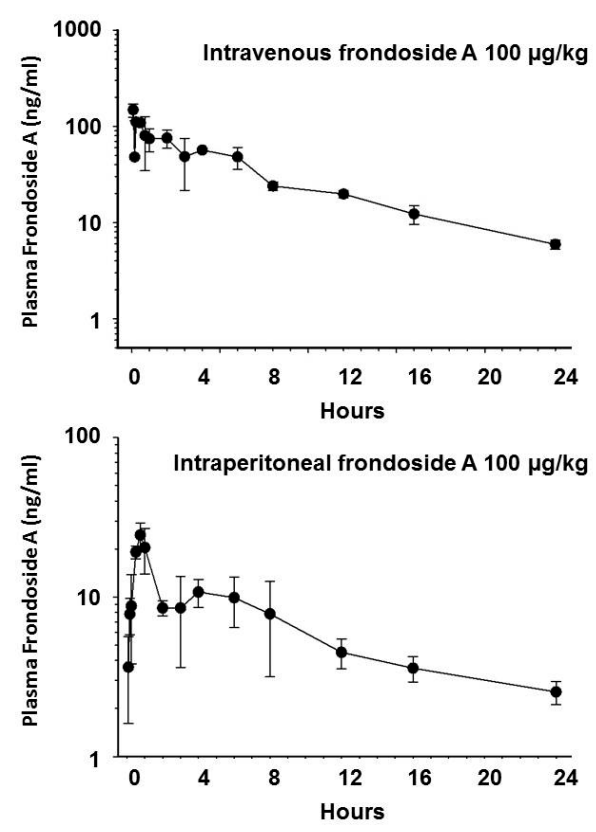

Figure 4. Plasma concentration of frondoside A versus time plot following administration of frondoside A at a dose of $100 \mu \mathrm{g} / \mathrm{kg}$ intravenously or intraperitoneally in CD2F1 mice. Each point represents the mean and SD of plasma concentration in five animals. 
Table 1. Pharmacokinetics of frondoside A following bolus injection of $100 \mu \mathrm{g} / \mathrm{kg}$ in $0.7 \%$ DMSO in saline, either intraperitoneally or intravenously, in 10 male $\mathrm{CD}_{2} \mathrm{~F}_{1}$ mice.

\begin{tabular}{ccc}
\hline Parameter & IP Bolus & IV Bolus \\
\hline Area under curve $(\mathrm{AUC}) \mu \mathrm{g} / \mathrm{L} \times \mathrm{min}$ & 9984 & 47,220 \\
Total body clearance $\left(\mathrm{Cl}_{\mathrm{tb}}\right) \mathrm{mL} / \mathrm{min} / \mathrm{m}^{2}$ & 127 & 6.35 \\
Maximum plasma concentration $\left(\mathrm{C} \mathrm{p}_{\max }\right) \mathrm{nM}$ & 18.3 & 129 \\
Bioavailability $(\%)$ & 20 & 100 \\
Apparent volume of distribution $\left(\mathrm{L} / \mathrm{m}^{2}\right)$ & 28 & - \\
Volume of distribution $\left(\mathrm{L} / \mathrm{m}^{2}\right)$ & - & 0.87 \\
Half-life $\gamma\left(\mathrm{T}_{\frac{1}{2}} \gamma\right)$ minutes & 840 & 510 \\
Half-life $\alpha\left(\mathrm{T}_{\frac{1}{2}} \alpha:\right.$ distribution phase $)$ minutes & - & 2 \\
Half-life $\beta\left(\mathrm{T}_{\frac{1}{2}} \beta\right.$ elimination phase) minutes & - & 158 \\
\hline
\end{tabular}

\section{Discussion}

In recent years, there has been considerable interest in sea cucumber-derived triterpenoid glycosides as anti-cancer agents. Frondoside A, from the Atlantic sea cucumber Cucumaria frondosa, has potent anti-cancer effects in cancers of the pancreas, lung, breast, prostate, and in leukemias, both in vitro and in vivo [4-8]. Frondoside A, causes cell cycle arrest, inhibits proliferation, and induces apoptosis [4,6,7]. In addition, frondoside $\mathrm{A}$ inhibits angiogenesis, invasion and metastases [5-7]. Frondoside A also potentiates the effects of other anti-cancer agents [9].

Frondoside A appears to be safe, with no apparent side effects, body weight, liver function and haematological parameters are not altered in animals that have received daily therapeutic doses of up to 10 or $100 \mu \mathrm{g} / \mathrm{kg} /$ day for one month $[4-6,10]$. The $\mathrm{LD}_{50}$ determined in previous studies was approximately $10 \mathrm{mg} / \mathrm{kg}$, which is 100 -fold greater than the high therapeutic dose used in previous preclinical experiments [10].

From the present studies it is clear that frondoside A has a more potent effect than frondoside $B$ in vitro, while frondoside $C$ had no effect at all in the concentration range tested. Similarly, the aglycone had no effect, while frondoside A inhibited proliferation with an $\mathrm{IC}_{50}$ of approximately $1 \mu \mathrm{M}$.

In the mouse xenograft experiment, intraperitoneal administration of frondoside A had a marked and highly significant inhibitory effect on tumor growth compared with vehicle control; tumor weights at the end of the experiment were less than $30 \%$ of the vehicle-treated controls. In contrast, orally administered frondoside $\mathrm{A}$ at the same daily dose had no significant effect on tumor size throughout the experiment or tumor weight at the end. These findings suggest that frondoside A is either not absorbed intact from the gut in any significant quantity or is rapidly metabolized by the animal's digestive enzymes to inactive compounds. It is likely that the glycosyl groups are digested during passage through the gut and, as shown above, the aglycone has no tumor-inhibitory activity. This was corroborated by the pharmacokinetic studies that showed that plasma frondoside A levels after intravenous administration at a dose of $500 \mathrm{mg} / \mathrm{kg}$ were approximately $700-800 \mathrm{ng} / \mathrm{mL}$, while they were approximately $100-120 \mathrm{ng} / \mathrm{mL}$ after intraperitoneal administration and were at or below the limit of detection of the assay $(5 \mathrm{ng} / \mathrm{mL})$ after oral administration. This data indicates that frondoside $A$ is most effective when administered intravenously and is ineffective when administered through the oral route.

In summary, the additional sulphate group on frondoside B renders it less effective as an anticancer agent than frondoside $\mathrm{A}$. The addition of two sulphate groups in frondoside $\mathrm{C}$, or the removal of the glycoside moieties from the frondosides (to produce the aglycone) results in complete loss of activity. Frondoside A appears not to be absorbed intact from the gastrointestinal tract and is only effective as an anticancer agent when administered parenterally. 


\section{Materials and Methods}

\subsection{Isolation and Purification of Frondoside A, B, C and Their Aglycone}

Frondosides (A, B and C) were isolated and purified as previously described [10]. For structures of these three compounds see Figure 5. A Biotage (Charlottesville, VA, USA) Si 40L 2632-2 flash column was used to separate mono-, di-, and trisulfated (frondoside $\mathrm{A}, \mathrm{B}$ and $\mathrm{C}$ respectively) glycoside fractions using chloroform/ethanol/water (100:100:17, by volume) as a solvent system. For this, a part of crude glycoside fraction was dissolved in a minimal volume with the same solvent mixture and water by drops and loaded into the column. The column was then eluted with $0.5 \mathrm{~L}$ of the same solvent mixture with subsequent collections of $10-\mathrm{mL}$ fractions. After completion of the frondoside A elution, the solvent mixture was changed to chloroform/ethanol/water (100:150:50 by volume). Eluting fractions were checked with thin-layer chromatography. The thin-layer chromatography solvent system was chloroform/ethanol/water (100:100:17 by volume). As a result, frondoside A (50 mg), a fraction of disulfated glycosides $(136 \mathrm{mg}$ ) (frondoside B), and a fraction of trisulfated glycosides (171 mg) (frondoside $\mathrm{C}$ ) were obtained. The aglycone was prepared by acid hydrolysis [12].

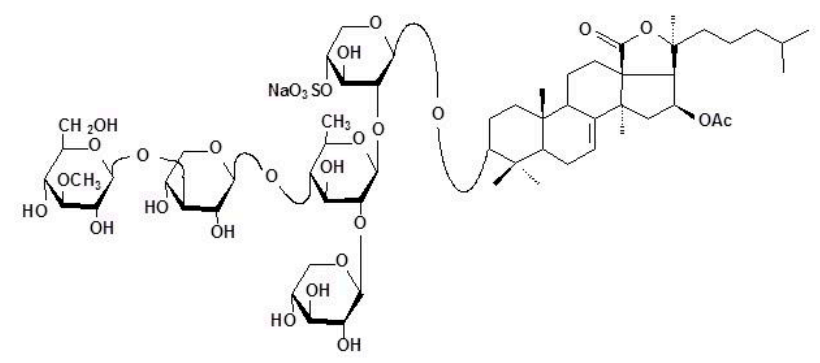

Frondoside A

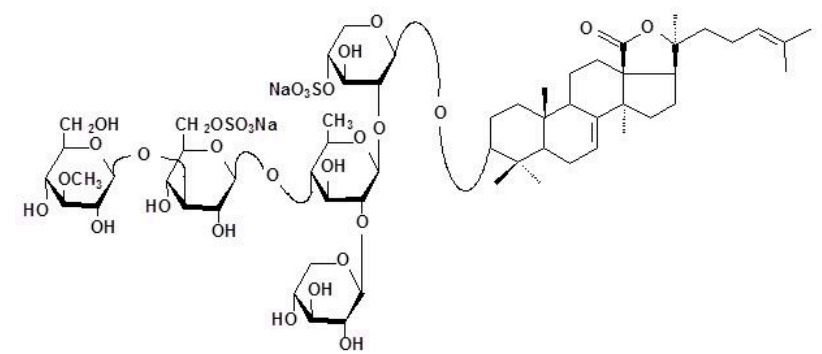

Frondoside B

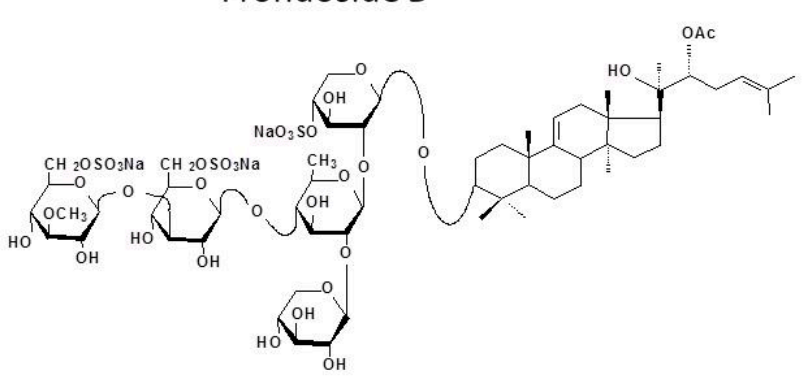

Frondoside C

Figure 5. Structures of frondosides A, B, C (mono, di and tri-sulphated frondoside).

\subsection{Cell Lines and Cell Cultures}

The pancreatic cancer cell lines chosen for these studies, AsPC-1 and S2013 are both highly malignant and produce rapidly growing tumors in athymic mice. AsPC-1 is a poorly differentiated cell line derived from nude mouse xenograft initiated with cells from the ascites of a patient with 
pancreatic cancer (American Type Culture Collection (Manassas, VA, USA)) [13]. S2-013, a subclone of SUIT-2, is a well-differentiated cell line derived from a liver metastasis of human pancreatic cancer [14]. The S2-013 cells were cultured in Dulbecco's Modified Eagles Medium (DMEM) and the AsPC-1 cells were grown in RPMI. Both media were supplemented with $10 \%$ fetal bovine serum, penicillin (100 units $/ \mathrm{mL}$ ), streptomycin $(100 \mu \mathrm{g} / \mathrm{mL})$ (Gibco, Grand Island, NY, USA) at $37^{\circ} \mathrm{C}$ in humidified air with $5 \% \mathrm{CO}_{2}$ for $24 \mathrm{~h}$. Then cells were transferred into serum-free media after washing twice with PBS and incubated for $24 \mathrm{~h}$ in 24 -well plates. Cells then were treated in fresh serum-free media with different concentrations of frondoside $\mathrm{A}$, frondoside $\mathrm{B}$, frondoside $\mathrm{C}$ and their aglycone and kept for incubation for 24 to $48 \mathrm{~h}$. Cells were harvested by incubation in trypsin-EDTA solution for $10 \mathrm{~min}$. Cells were then centrifuged at $2000 \times g$ for $2 \mathrm{~min}$ and cell pellets were suspended in fresh serum free media prior to measuring cell proliferation.

\subsection{Cell Proliferation Assays}

Cell proliferation was measured by counting the number of viable cells (Guava ViaCount) on Guava on an EasyCyte Plus cytometer (Millipore, Hayward, CA, USA).

\subsection{Animals and Subcutaneous Tumor Cell Implantation}

AsPC-1 cells were seeded into $75 \mathrm{~cm}^{2}$ flasks and cultured in a humidified atmosphere of $95 \% \mathrm{O}_{2}$ and $5 \% \mathrm{CO}_{2}$ at $37{ }^{\circ} \mathrm{C}$, and media was changed every other day. The tumor cells were trypsinized, cell number counted (Guava EasyCytePlusCytometer) and then re-suspended in PBS.

For cancer xenografts 6-8 week old athymic nude mice were bred in the animal facility. Breeding stock was NMRI female nude mice $(n u / n u$, Charles River, Suizfeld, Germany). The mice were housed in micro-isolator cages in a filtered-air laminar flow isolation chamber and handled under aseptic conditions (EuroBioConcept, Paris, France). They were fed with autoclaved laboratory rodent food pellets and acclimatized to the facility for two weeks prior to tumor cell implantation. Animal weights were recorded every third day. The animal protocol was approved by the Institutional Animals Care and Use Committee and all procedures were conducted in accordance with Institutional Guidelines that are in compliance with Faculty of Medicine \& Health Sciences, national and international laws and policies (EEC Council Directive 86/609, OJ L 358, 1; and NIH Guide for Care and Use of Laboratory Animals, NIH Publication No. 85-23).

Six million AsPC-1 human pancreatic cancer cells were injected into each flank of the athymic mice. Once tumors were established and had reached approximately $250 \mathrm{~mm}^{3}, 7$ days after injection, the mice were randomized into 3 groups with 6 mice per group: Group I (Control) received daily i.p. injections of vehicle (100 $\mu \mathrm{L} \mathrm{0.2 \%} \mathrm{DMSO);} \mathrm{Group} \mathrm{II} \mathrm{(frondoside} \mathrm{A)} \mathrm{received} \mathrm{daily} \mathrm{i.p.} \mathrm{injections} \mathrm{of}$ frondoside A $100 \mu \mathrm{g} / \mathrm{kg} /$ day $(4 \mu \mathrm{L} / \mathrm{g}$ of $25 \mu \mathrm{g} / \mathrm{mL} 0.2 \%$ DMSO); Group III (frondoside A) received daily oral dose of frondoside A $100 \mu \mathrm{g} / \mathrm{kg} /$ day $(4 \mu \mathrm{L} / \mathrm{g}$ of $25 \mu \mathrm{g} / \mathrm{mL} 0.2 \%$ DMSO);. Animal weight and tumor size were recorded every third day. The formula for calculating tumor volume was: (length) $\times($ width $) \times($ length + width $/ 2) \times 0.526=$ volume [15]. After 30 days of treatment the animals were euthanized and the tumors were carefully dissected and tumor weights measured. Tissues were fixed in $4 \%$ formaldehyde, which was replaced with $70 \%$ ethanol after $24 \mathrm{~h}$. Tissues were then paraffin embedded according to histology standard protocols.

\subsection{Pharmacokinetics of Frondoside A}

An LC-MS/MS method was developed and validated for the measurement of frondoside A in mouse and human plasma. Frondoside A was extracted from plasma as follows. A $100 \mathrm{mg}$ C18-E extraction cartridge (Phemonenex, Torrance, CA, USA) was prepared by washing with $1 \mathrm{~mL}$ methanol followed by $1 \mathrm{~mL}$ water. Samples $(100 \mu \mathrm{L}$ plasma $+400 \mu \mathrm{L}$ water) were then loaded onto the cartridge followed by washing with $1 \mathrm{~mL}$ water. The wash was discarded and frondoside eluted using $3 \mathrm{~mL}$ of a solution containing methanol:acetonitrile:acetic acid (60:40:0.1, V:V:V). The eluent was dried at $40{ }^{\circ} \mathrm{C}$ 
and reconstituted with $100 \mu \mathrm{L}$ of 1:1 methanol: $10 \mathrm{mM}$ ammonium acetate. Samples were vortexed for $30 \mathrm{~s}$ and then transferred to a clean vial for injection onto the LC/MS/MS.

Chromatography was carried out by injection of $25 \mu \mathrm{L}$ aliquots of extracted plasma samples on a Phenomenex Luna C5 column $(50 \times 2 \mathrm{~mm})$ using an elution gradient with $10 \mathrm{mM}$ ammonium acetate, $\mathrm{pH} 8.5$ and methanol, at a flow rate of $300 \mu \mathrm{L} / \mathrm{min}$ at $60^{\circ} \mathrm{C}$. The column was connected to a MicroMass Quatro Ultima tandem mass spectrometer (Waters Corp., Milford, MA, USA) operated in electrospray negative mode. Compounds were detected at $m / z 1331.5 \rightarrow 1331.5$, with bardoxolone methyl ester $(\mathrm{CDDO})$ as an internal standard (MS/MS at $m / z 490.4 \rightarrow 416.2$ ).

Pilot studies were conducted in $\mathrm{CD}_{2} \mathrm{~F}_{1}$ mice to determine the optimal doses for the subsequent pharmacokinetic studies. The definitive studies on pharmacokinetics were performed in $\mathrm{CD}_{2} \mathrm{~F}_{1}$ mice with intravenous (i.v.) or intraperitoneal (i.p.) administration of frondoside A at $100 \mu \mathrm{g} / \mathrm{kg}$. Blood was collected from 5 animals per time point, the plasma collected, solid-phase extracted and frondoside A levels measured using the LC-MS/MS methods described above. Concentration-time data were fitted by non-linear least-squares regression.

\subsection{Statistical Analysis}

All data were analyzed using analysis of variance (ANOVA) with Bonferroni's or Dunnett's corrections for multiple comparisons as appropriate. The growth curves for tumor growth in vivo were analyzed as incremental area under the curve for statistical purposes. Differences were considered statistically significant when $p \leqslant 0.05$. Graphs were created using either GraphPad Prism or SigmaPlot software.

\section{Conclusions}

Frondoside $\mathrm{A}$ is a more effective anticancer agent than frondoside B. Frondoside $\mathrm{C}$ and the aglycone have no anticancer activity. Frondoside A appears not to be absorbed intact from the gastrointestinal tract in significant amounts and is only effective as an anticancer agent when administered parenterally. Frondoside A may be valuable in the treatment of cancer.

Acknowledgments: These studies were partially funded by a pre-clinical development RAID grant (\#259) from the National Cancer Institute, Bethesda, MD; by a grant from the Terry Fox Cancer Fund for Research in Cancer Therapy. Coastside Bio Resources received funding from the Maine Technology Institute, Brunswick, Maine.

Author Contributions: J.A.S., R.A.N., B.H., P.C. and T.E.A. conceived and designed the experiments; J.A.S., K.A.P., A.A., C.W. performed the experiments; J.A.S., K.A.P., R.A.N, P.C. and T.E.A. analyzed the data; P.C. contributed the frondosides and aglycone; J.A.S., R.A.N. and T.E.A. wrote the paper.

Conflicts of Interest: P.C. and T.E.A. are holders of patents: WO2005072528 and US2005288239-A1, concerning the use of frondoside A in cancer therapy. The other authors declare no conflict of interest. The funding sponsors had no role in the design of the study; in the collection, analyses, or interpretation of data; in the writing of the manuscript, and in the decision to publish the results.

\section{Abbreviations}

The following abbreviations are used in this manuscript:

$\begin{array}{ll}\mathrm{AUC} & \text { Area under curve } \\ \mathrm{Cl}_{\mathrm{tb}} & \text { Total body clearance } \\ \mathrm{C} p_{\max } & \text { Maximum plasma concentration } \\ \mathrm{CV} & \text { Coefficient of variation } \\ \mathrm{DMSO} & \text { Dimethyl sulphoxide } \\ \mathrm{LOD} & \text { Limit of detection } \\ \mathrm{V}_{\mathrm{D}} & \text { Volume of distribution }\end{array}$

\section{References}

1. Siegel, R.; Ma, J.; Zou, Z.; Jemal, A. Cancer Statistics. CA Cancer J. Clin. 2014, 64, 9-29. [CrossRef] [PubMed]

2. Saif, M.W. Pancreatic Neoplasm in 2011: An Update. JOP J. Pancreas 2011, 12, 316-321. 
3. Al Haddad, A.H.; Adrian, T.E. Challenges and future directions in therapeutics for pancreatic ductal adenocarcinoma. Expert Opin. Investig. Drugs 2014, 23, 1499-1515. [CrossRef] [PubMed]

4. Li, X.; Roginsky, A.B.; Ding, X.Z.; Woodward, C.; Collin, P.; Newman, R.A.; Bell, R.H., Jr.; Adrian, T.E. Review of the apoptosis pathways in pancreatic cancer and the anti-apoptotic effects of the novel sea cucumber compound, Frondoside A. Ann. N. Y. Acad. Sci. 2008, 1138, 181-198. [CrossRef] [PubMed]

5. Al Marzouqi, N.; Iratni, R.; Nemmar, A.; Arafat, K.; Al Sultan, A.M.; Yasin, J.; Collin, P.; Mester, J.; Adrian, T.E.; Attoub, S. Frondoside A inhibits human breast cancer cell survival, migration, invasion and the growth of breast tumor xenografts. Eur. J. Pharmacol. 2011, 668, 25-34. [CrossRef] [PubMed]

6. Attoub, S.; Arafat, K.; Gélaude, A.; Al Sultan, M.A.; Bracke, M.; Collin, P.L.; Takahashi, T.; Adrian, T.E.; De Wever, O. Frondoside a suppressive effects on lung cancer survival, tumor growth, angiogenesis, invasion, and metastasis. PLoS ONE 2013, 8, e53087. [CrossRef] [PubMed]

7. Ma, X.; Kundu, N.; Collin, P.D.; Goloubeva, O.; Fulton, A.M. Frondoside A inhibits breast cancer metastasis and antagonizes prostaglandin E receptors EP4 and EP2. Breast Cancer Res. Treat. 2011, 132, 1001-1008. [CrossRef] [PubMed]

8. Jin, J.O.; Shastina, V.V.; Shin, S.W.; Xu, Q.; Park, J.I.; Rasskazov, V.A.; Avilov, S.A.; Fedorov, S.N.; Stonik, V.A.; Kwak, J.Y. Differential effects of triterpene glycosides, frondoside A and cucumarioside A2-2 isolated from sea cucumbers on caspase activation and apoptosis of human leukemia cells. FEBS Lett. 2009, 583, 697-702. [CrossRef] [PubMed]

9. Al Shemaili, J.; Mensah-Brown, E.; Parekh, K.; Thomas, S.A.; Attoub, S.; Hellman, B.; Nyberg, F.; Adem, A.; Collin, P.; Adrian, T.E. Frondoside A enhances the antiproliferative effects of gemcitabine in pancreatic cancer. Eur. J. Cancer 2014, 50, 1391-1398. [CrossRef] [PubMed]

10. Aminin, D.L.; Agafonova, I.G.; Kalinin, V.I.; Silchenko, A.S.; Avilov, S.A.; Stonik, V.A.; Collin, P.D.; Woodward, C. Immunomodulatory properties of frondoside A, a major triterpene glycoside from the North Atlantic commercially harvested sea cucumber Cucumaria frondosa. J. Med. Food 2008, 11, 443-453. [CrossRef] [PubMed]

11. Aminin, D.L.; Koy, C.; Dmitrenok, P.S.; Müller-Hilke, B.; Koczan, D.; Arbogast, B.; Silchenko, A.A.; Kalinin, V.I.; Avilov, S.A.; Stonik, V.A.; et al. Immunomodulatory effects of holothurian triterpene glycosides on mammalian splenocytes determined by mass spectrometric proteome analysis. J. Proteom. 2009, 72, 886-906. [CrossRef] [PubMed]

12. Girard, M.; Bélanger, J.; ApSimon, J.W.; Garneau, F.-X.; Harvey, C.; Brisson, J.R. Frondoside A. A novel triterpene glycoside from the holothurian Cucumaria frondosa. Can. J. Chem. 1990, 68, 11-18.

13. Chen, W.H.; Horoszewicz, J.S.; Leong, S.S.; Shimano, T.; Penetrante, R.; Sanders, W.H.; Berjian, R.; Douglass, H.O.; Martin, E.W.; Chu, T.M. Human pancreatic adenocarcinoma: In vitro and in vivo morphology of a new tumor line established from ascites. In Vitro 1982, 18, 24-34. [CrossRef] [PubMed]

14. Iwamura, T.; Taniguchi, S.; Kitamura, N.; Yamanari, H.; Kojima, A.; Hidaka, K.; Setoguchi, T.; Katsuki, T. Correlation between CA19-9 production in vitro and histological grades of differentiation in vivo in clones isolated from a human pancreatic cancer cell line (SUIT-2). J. Gastroenterol. Hepatol. 1992, 7, 512-519. [CrossRef] [PubMed]

15. Tong, W.G.; Ding, X.-Z.; Hennig, R.; Witt, R.C.; Standop, J.; Pour, P.M.; Adrian, T.E. Leukotriene B4 receptor antagonist LY293111 inhibits proliferation and induces apoptosis in human pancreatic cancer cells. Clin. Cancer Res. 2002, 8, 3232-3242. [PubMed]

(C) 2016 by the authors; licensee MDPI, Basel, Switzerland. This article is an open access article distributed under the terms and conditions of the Creative Commons Attribution (CC-BY) license (http:/ / creativecommons.org/licenses/by/4.0/). 